\title{
UPAYA PENINGKATAN MUTU PEMBELAJARAN MEMBACA MELALUI PENERAPAN MODEL PEMBELAJARAN ARIAS \\ DENGAN BERBANTUAN TEKNIK COMPLETE SENTENCE \\ PADA SISWA KELAS IX.B SMP NEGERI 3 TAMPAKSIRING \\ TAHUN AJARAN 2010/2011
}

\author{
I Wayan Gede Punarbhawa \\ SMP Negeri 3 Tampaksiring
}

\begin{abstract}
ABSTRAK
Penelitian ini bertujuan untuk meningkatkan aktivitas siswa dalam pembelajaran membaca dan untuk meningkatkan kompetensi hasil belajar siswa dalam pengajaran membaca berdasarkan penerapan Model Pembelajaran ARIAS dengan berbantuan Teknik Complete Sentence. Pengumpulan data dilakukan melalui observasi, wawancara dan tes membaca dan analisisnya mengunakan analisis deskriptif kualitatif dan deskriptif kuantitatif. Hasil penelitian menunjukkan bahwa terjadi peningkatkan mutu pembelajaran membaca siswa yaitu nilai rata- rata awal 59,52 dengan ketuntasan 21,43\% meningkat menjadi 69,05 dengan ketuntasan 61,90\% pada siklus I dan 72,50 dengan ketuntasan $80,95 \%$ pada siklus II. Simpulannya adalah Penerapan Model Pembelajaran ARIAS dengan Berbantuan Teknik Complete Sentence dapat meningkatkan aktivitas dan kompetensi dalam memahami isi bacaan Siswa Kelas IX.B SMP Negeri 3 Tampaksiring Tahun Ajaran 2010/2011.
\end{abstract}

Kata Kunci: Model Pembelajaran ARIAS, Teknik Complete Sentence, Pembelajaran Membaca

\begin{abstract}
This research aims to increase the activity of students in learning to read and to improve the competence of student learning outcomes in reading by applying ARIAS Learning Model assisted with Complete Sentence technique. Data collection is done through observation, interviews and reading tests. The results were then analyzed using descriptive analysis both qualitative and quantitative. From the results it showed that there was increasing quality of students in learning to read with the average beginning value mastery of $21.43 \% 59.52$ increased to 69.05 by $61.90 \%$ completeness in the first cycle and 72.50 to $80.95 \%$ mastery on the second cycle. The conclusion is Implementation of the Assisted Learning Model ARIAS with Sentence Complete Technique can increase the activity and competence in understanding the content of reading texts of the IX.B grade students of SMP Negeri 3 Tampaksiring in Academic Year 2010/2011.
\end{abstract}

Keywords: Learning Model ARIAS, Complete Sentence, Reading 


\section{PENDAHULUAN}

Dalam Kurikulum 2004 yang berbasis kompetensi (KBK), yang telah disempurnakan menjadi Kurikulum Tingkat Satuan Pendidikan (KTSP), pengajaran Bahasa dan Sastra Indonesia pada jenjang Pendidikan Dasar (SMP/MTs) menuntut agar subjek didik memiliki kemampuan (kompetensi) berbahasa dan kompetensi bersastra. Baik kompetensi berbahasa maupun kompetensi bersastra mencakup empat aspek keterampilan berbahasa. Keempat aspek itu adalah mendengarkan (menyimak), berbicara, membaca dan menulis (Depdiknas, 2004 : 79).

Sehubungan dengan aspek keterampilan membaca, Kurikulum Tingkat Satuan Pendidikan yang Berbasis Kompetensi menuntut agar siswa memiliki kompetensi membaca secara efektif dan efisien dalam berbagai konteks, memiliki kompetensi mengungkapkan berbagai pikiran, gagasan, pendapat dan perasaan yang tertuang dalam berbagai ragam tulisan (Depdiknas, 2004 : 77).

Maka benar apa yang dikemukakan oleh Rahim ( 2007 : 99). Mengemukakan bahwa siswa berhasil dalam proses pembelajaran dalam berbagai mata pelajaran ditentukan oleh kemampuan membaca. Sehingga benar apa yang dinyatakan oleh Soedarsono. (2002 : 1). Beliau mengakatan bahwa keterampilan membaca memiliki nilai strategis bagi seseorang dalam upaya pengembangan diri. Tanpa memiliki keterampilan membaca seseorang akan buta terhadap segala informasi yang ada. Hidup seseorang seolah-olah tanpa cahaya yang menerangi jalan sehingga membuat celaka pada dirinya sendiri.

Walaupun pembelajaran keterampilan membaca sudah diajarkan lama sejak mulai adanya kurikulum 1968, 1975, 1984, 1994 hingga KTSP, dan berbagai pendekatan, teknik, serta model pembelajaran yang diterapkan, siswa khususnya siswa tempat penulis bertugas masih lemah dalam keterampilan membaca. Sebagai indikator, banyak rekan penulis pada mata pelajaran lain mengeluhkan ketidakmampuan siswa memahami isi bacaan pada buku sumber yang dipakai sumber pembelajaran. Memperkuat indikator tersebut, refleksi awal yang penulis lakukan pada siswa ternyata ditemukan bahwa rata-rata nilai membacanya 50,15. Rata-rata ini belum mencapai nilai KKM yang 
diharapkan yaitu 70. Dari 44 siswa yang ikut dalam refleksi awal hanya 9 orang mampu mencapai nilai KKM. Ini berarti tingkat ketuntasannya baru 21,43\%. Ketuntasan ini belum mencapai target yang diharapkan yaitu minimal ketuntasan yang diharapkan adalah $75 \%$.

Jika dicermati, ada beberapa faktor yang dapat diduga menyebabkan siswa rendah memahami isi bacaan. Satu diantaranya yang paling urgen adalah faktor minat baca siswa. Hal ini diperkuat oleh apa yang dikemukakan oleh Sumadi bahwa faktor yang paling kuat yang menyebabkan siswa mengalami kesulitan memahami isi bacaan adalah minat baca siswa itu sendiri (dalam Soedarsono., 2002 : 44). Ini bisa diartikan jika minat baca siswa tinggi kemungkinan besar siswa lebih mudah memahami isi bacaan daripada minat baca siswa rendah. Berkaitan dengan minat baca ini faktor pengiringnya adalah faktor kesadaran siswa akan arti pentingnya membaca dalam kehidupan sehari-hari. Banyak siswa yang belum menyadari bahwa dengan membaca banyak memberikan dampak positif bagi dirinya sendiri. Akibat dari kedua hal tadi siswa saat melakukan proses membaca kurang memiliki konsentrasi dalam menghadapi bahan bacaan. Padahal, menurut Nuriadi (2008 : 12) faktor kemampuan berkonsentrasi merupakan hal yang mutlak bagi seseorang pembaca yang efesien dan efektif.

Hal lain yang dapat diketahui berkaitan dengan prilaku guru bahwa dalam pengelolaan kelas selama mengasuh pembelajaran keterampilan membaca, guru lebih banyak menjelaskan dengan metode ceramah, lebih banyak otoriter sehingga pembelajaran berpusat pada guru. Upaya yang selama ini dilakukan cenderung menyuapi siswa dengan teori. Cara seperti itu berorientasi pada produk bukan proses. Pembelajaran berpusat kepada guru dan pola interaksi hanya satu arah. Padahal Kurikulum Tingkat Satuan Pendidikan (KTSP) yang berbasis kompetensi berorientasi pada proses dan sekaligus produk serta pola interaksi dalam pembelajaran diharapkan multi arah. Upaya-upaya guru semacam itu kurang membimbing dan memberi pengalaman langsung kepada siswa. Selain itu, guru jarang menyediakan wacana yang baik sebagai model bagi siswa. Guru kurang menuntun siswa dalam proses membaca. Padahal guru diharapkan 
memiliki kompetensi untuk memilih pendekatan, metode dan teknik serta tindakan-tindakan yang tepat sehingga proses pembelajaran dapat berlangsung efektif dan efesien. Jika dicermati Kurikulum Tingkat Satuan Pendidikan (KTSP) yang Berbasis Kompetensi menyediakan sejumlah langkah pembaharuan di dalam pengajaran bahasa Indonesia. Pemahaman terhadap hal-hal yang terkandung di dalamnya membuat proses belajar mengajar di kelas menjadi kegiatan yang menarik dan menyenangkan bagi siswa. Sehubungan dengan itu, guru mata pelajaran Bahasa Indonesia diharapkan dapat menampilkan setiap materi pelajaran dengan pendekatan, metode serta tindakan-tindakan agar menjadi sesuatu yang menarik bagi siswa sehingga apa yang menjadi indikator keberhasilan pembelajaran dapat dicapai. Guru diharapkan mempunyai wawasan bahwa siswa belajar secara aktif, siswa mempelajari berbagai hal secara terus menerus dalam perjalanan hidupnya. Pembelajaran diharapkan berpusat pada diri siswa dan multi arah. Persoalan tersebut sudah berlarut-larut menjadi permasalahan oleh guru kolega penulis di SMP Negeri 3 Tampaksiring.
Namun, belum ditemukan salah satu upaya tindakan yang harus diambilnya. (1) Sehubungan dengan itu, jika kondisi ini dibiarkan dampaknya akan buruk pada prestasi belajar siswa pada setiap mata pelajaran. Karena itu, kondisi di atas harus segera diatasi. Dalam mengatasi permasalahan ini peneliti berupaya untuk memecahkan masalah yang ada. Untuk itu peneliti mencoba penggunaan Model Pembelajaran ARIAS dengan berbantuan Teknik Complete Sentence untuk meningkatkan aktivitas siswa kelas IX B SMP Negeri 3 Tampaksiring dalam pembelajaran membaca?

Berdasarkan Kurikulum Tingkat Satuan Pendidikan (KTSP) yang berbasis kompetensi, kompetensi dasar yang mesti diajarkan kepada siswa mencakup empat komponen. Keempat komponen yang dimaksud adalah (1) mendengarkan, (2) berbicara, (3) membaca, dan (4) menulis. Keempat komponen tersebut diajarkan secara integratif dan alamiah (Depdiknas, 2005 : 77). Sehubungan dengan aspek membaca, standar kompetensi bahan kajiannya adalah membaca secara efektif dan efisien dalam berbagai konteks, memiliki kompetensi 
mengungkapkan berbagai pikiran, ini didukung oleh Bandura. Oleh gagasan, pendapat dan perasaan yang Bandura dikatakan bahwa seseorang tertuang dalam berbagai ragam tulisan yang memiliki sikap pecaya diri tinggi (Depdiknas, 2004 : 77).

Model Pembelajaran ARIAS cenderung akan berhasil bagaimanapun kecilnya kemampuan yang ia miliki. (Assurance, Relevance, Interest, Assesment, Satisfaction). Dalam kaitan pembelajaran membaca, siswa atau pembaca saat melakukan aktivitas membaca akan berusaha secara maksimal memahami isi teks bacaan. Tarjo/http (2009) mengemukakan bahwa dalam usahanya siswa memahami isi teks bacaan, dalam proses pembelajaran perlu diterapkan beberapa teknik yang relevan. Salah satu teknik yang bisa membantu model pembelajaran ARIAS ini adalah Teknik Complete Sentence (dalam http://wijayalabs.wordpress.com/2008/ 04/22). Bahkan dalam http://wyw1d.wordpress.com/2009/11/

14) dikatakan bahwa Teknik Complete Sentence ini sangat cocok dalam pembelajaran untuk mata pelajaran Bahasa Indonesia.

Assurance (percaya diri) sangat diperlukan siswa dalam proses pembelajaran (Keller, 1987 : 2-9, dalam http://wijayalabs.wordpress.com/2008/ 04/22/). Apa yang disampaikan Keller Sikap seseorang merasa yakin, penuh percaya diri dapat berhasil mencapai sesuatu akan mempengaruhi mereka dalam bertingkah laku untuk mencapai keberhasilan (Gagne dan Driscoll, $1988 \quad$ : $\quad 70, \quad$ dalam http://wijayalabs.wordpress.com/2008/ 04/22/). Bahkan oleh Prayitno (1989 : 42 , dalam http://wijayalabs.wordpress.com/2008/ 04/22/) dikatakan bahwa siswa yang memiliki sikap percaya diri dan memiliki penilaian positif tentang dirinya cenderung menampilkan prestasi yang baik secara terus menerus. Relevance merupakan hal berhubungan dengan kehidupan siswa baik berupa pengalaman sekarang maupun yang telah dimilikinya ataupun yang berhubungan dengan kebutuhan karier sekarang atau yang akan datang Interest adalah hal yang berkaitan dengan minat dan perhatian siswa terhadap sesuatu yang dipelajarinya. Menurut Woodruff seperti yang dikutip oleh Gredler, M.E.Bell (1991 : 23) dikatakan bahwa sesungguhnya proses 
belajar tidak terjadi tanpa adanya minat atau perhatian dari yang belajar. Assesment adalah hal yang berhubungan dengan evaluasi atau penilaian terhadap perkembangan belajar siswa . Perkembangan belajar siswa tentunya wajib diketahui guru. Evaluasi merupakan bagian pokok yang dapat memberi keuntungan bagi guru dan siswa itu sendiri. Satisfaction adalah hal yang berhubungan dngan rasa bangga, puas akan hasil yang dicapai sekalipun hasil itu masih kecil. ). Siswa yang telah berhasil mengerjakan atau mencapai sesuatu merasa puas dan bangga akan keberhasilannya itu. Keberhasilan dan kebanggannya itu bagi siswa menurut Gredler bisa mendorong untuk mencapai keberhasilan berikutnya (1991 : 121). Teknik Complete Sentence (Prosedure Cloze) dalam kaitannya pembelajaran membaca merupakan cara siswa melakukan kegiatan membaca untuk memahami isinya yang mana teks bacaan beberapa kalimatnya belum lengkap atau beberapa kata dari serangkaian kalimat dalam bacaan itu belum lengkap. Sehingga siswa harus melengkapinya terlebih dahulu Sebagai proses komunikasi, dalam kegiatan membaca, si pembaca akan memperoleh pesan atau pemahaman yang hendak disampaikan penulis melalui media tulisan (Tarigan, $1986: 7$ ). Berkenaan dengan ini, berarti dalam membaca terjadi proses komunikasi sebagai upaya membagi hasil observasi, informasi, pikiran, ide dan pengalaman penulis kepada pembaca.

\section{METODE}

Sebagai penelitian yang berbasis kelas dan bersifat siklikal, desain PTK ini mengikuti model Stephen Kemmis yang pada prinsipnya setiap siklus terdiri atas 4 tahapan yaitu (1) perencanaan (planning,) pelaksanaan tindakan (action), (3) observasi dan evaluasi (observation and evaluation) dan (4) refleksi (reflection) (Santyasa, $2006: 10)$. Penelitian Tindakan Kelas ini menggunakan desain model Stephen Kemmis dengan memiliki ciri yaitu variabel tindakan berupa penerapan Model Pembelajaran ARIAS (Assurance, Relevance, Interest, Assesment, Satisfaction ) dengan berbantuan Teknik Complete Sentence dan variabel hasil berupa meningkatnya kompetensi siswa dalam memahami bacaan. Sehubungan dengan penelitian 
ini, adapun penulis melaksanakan dalam dua siklus seperti bagan berikut.

Bagan 01 Desain Siklus Penelitian Tindakan Kelas

Siklus I $\rightarrow$ Refleksi awal $\rightarrow$
Perencanaan $\begin{gathered}\text { Tindakan } 1 \\ \text { Pelaksanaan Tindakan I } \rightarrow\end{gathered}$
dan evaluasi $\rightarrow$ Refleksi Siklus I $\rightarrow$
Siklus II $\rightarrow$ Perencanaan Tindakan 2
$\rightarrow \quad$ Pelaksanaan Tindakan $2 \rightarrow$
Observasi dan evaluasi $\rightarrow$ Refleksi
Siklus II $\rightarrow \rightarrow$ memutuskan tindakan
terbaik.

\section{Perencanaan Tindakan}

Berdasarkan atas estimasi penyebab yang telah dikemukakan di atas, kemudian ditetapkan rencana tindakan yang digunakan untuk mengatasinya. Dalam tahap perencanaan ini adapun langkahlangkah yang dilakukan penulis adalah sebagai berikut.

(1) Penulis menganalisis standar kompetensi, kompetensi dasar, indikator pembelajaran serta materi pelajaran yang harus diajarkan yang termuat dalam Kurikulum Bahasa Indonesia untuk dijabarkan dalam skenario pembelajaran (RPP).
(2) Penulis menyusun skenario pembelajaran (RPP) Kompetensi Dasar membaca dengan mengikuti rancangan pembelajaran berdasarkan Model Pembelajaran ARIAS (Assurance, Relevance, Interest, Assesment, Satisfaction) dengan Berbantuan Teknik Complette Sentence.

(3) Penulis menyusun instrumen penelitian yaitu pedoman observasi, angket wawancara, dan tes membaca.

\section{Pelaksanaan Tindakan}

(1) Penulis memberikan orientasi ataupun apersepsi materi pelajaran membaca dan strategi pembelajaran yang harus dilakukan serta menegaskan indikator dan tujuan pembelajaran yang ingin dicapai selama proses pembelajaran berlangsung.

(2) Penulis memberi pengarahan dan penjelasan kepada siswa untuk selalu percaya diri, memiliki minat belajar, dan memiliki kebanggaan atas kebehasilan yang telah diraihnya melalui ilustrasi cerita, penayangan model tokoh-tokoh besar dunia dan kata-kata motivasi dengan media power point.

(3) Penulis membagi siswa menjadi 10 kelompok. Tiap kelompok beranggotakan 4 orang sebanyak 8 kelompok dan 2 kelompok beranggotan 
5 orang karena jumlah siswa 42 orang.

Pembagian kelompok ini dilakukan dengan teknik siswa menghitung dari satu sampai sepuluh. Siswa yang menghitung satu masuk kelompok satu begitu seterusnya sampai hitungan sepuluh.

(4) Penulis membagikan LKS kepada seluruh kelompok yang berkaitan dengan membaca dengan teknik complete sentence.

(5) Penulis menjelaskan terkait dengan indikator dan tujuan pembelajaran yang harus dicapai. Selanjutnya, siswa berdiskusi dalam kelompok sesuai petunjuk dalam LKS.

(6) Penulis memberi kesempatan kepada tiap kelompok untuk menyampaikan hasil diskusinya. Masing-masing kelompok saling menanggapi, bisa menyanggah, memberi masukan dan penyempurnaan. Dalam setting ini penulis memberi penilaian kepada seluruh kelompok.

(7) Penulis bersama siswa melaksanakan refleksi terhadap proses pembelajaran yang telah berlangsung. Setelah itu, penulis menyampaikan format wawancara dan angket respon siswa terhadap pembelajaran yang dilaksanakan.

\section{Pertemuan Kedua}

(1) Penulis mempertegas kembali pertemuan pertama terutama yang berkaitan dengan teknik complete sentence dalam membaca.

(2) Selanjutnya penulis memberi tes membaca kepada setiap siswa sebagai bahan evaluasi.

\section{Refleksi}

Setiap selesai satu siklus selalu dilakukan refleksi terhadap proses pembelajaran yang telah dilaksanakan. Refleksi ini dilakukan berdasarkan hasil observasi, hasil wawancara, dan hasil tes membaca.

Jika hasil observasi, hasil wawancara, dan hasil tes membaca belum sesuai dengan harapan maka dilanjutkan pada tindakan pembelajaran pada siklus berikutnya. Jika ternyata belum ada peningkatan kompetensi membaca seperti yang diharapkan, tindakan-tindakan proses pembelajaran itu didaur ulang pada siklus berikutnya dengan diadakan perbaikan (modifikasi), namun yang dipandang sudah baik tetap dipertahankan berdasarkan hasil refleksi sebelumnya sampai ditemukan hasil peningkatan kompetensi siswa dalam membaca. Sebaliknya, bila sudah memenuhi harapan maka dalam 
refleksi diambil keputusan atau penyimpulan.

\section{HASIL DAN PEMBAHASAN}

\section{Hasil}

Hasil yang diperoleh dari penelitian ini, kemampuan siswa awal sebelum diberi tindakan baru mencapai nilai rata-rata 59,52 dengan persentase ketuntasan belajar $21,43 \%$. meningkat menjadi 69,05 dengan ketuntasan $61,90 \%$ pada siklus I dan 72,50 dengan ketuntasan $80,95 \%$ pada siklus II.

\section{Tabel 1. Ringkasan Hasil}

\begin{tabular}{llll}
\hline & Awal & Siklus I & Siklus II \\
& & & \\
\hline Respon & & 29,05 & 29,69 \\
Siswa & & (Positif) & (Positif) \\
\hline Nilai & 59,52 & 69,05 & 72,50 \\
Rata- & & & \\
Rata & & & \\
\hline Ketuntasa & 21,43 & $61,90 \%$ & $80,95 \%$ \\
n & $\%$. & & \\
\hline
\end{tabular}

\section{Pembahasan}

Hasil penelitian merupakan jawaban terhadap permasalahan penelitian. Hasil penelitian ini lebih bermanfaat jika dibahas atau didiskusikan. Pembahasan ini didasarkan atas teori-teori yang relevan dan kerangka berpikir yang telah diuraian di depan.
Hasil penelitian ini menunjukkan bahwa respon siswa positif dengan pola interaksi baik dalam pembelajaran. Hal ini tampak pada hasil siklus I dan siklus II. Hal ini disebabkan oleh karakteristik model pembelajaran ARIAS yang memiliki komponenkomponen utama yang menantang dan membangkitkan rasa ingin tahu dan membangkitkan kepercayaan diri sehingga juga membangkitkan aktivitas siswa. Hal ini juga disebabkan karena Model Pembelajaran ARIAS memacu siswa untuk memiliki keyakinan dan sikap percaya diri untuk berhasil dalam pembelajaran

(Assurance), pembelajaran harus berhubungan dengan kehidupan nyata siswa baik berupa pengalaman sekarang atau yang akan datang (Relevance), keberhasilan dalam belajar harus adanya minat terhadap hal yang dipelajari (Interest), dalam belajar perlu adanya proses evaluasi baik selama proses pembelajaran berlangsung maupun pada akhir pembelajaran (Assesment), saat pembelajaran siswa harus memiliki rasa bangga terhadap keberhasilan yang dicapainya, sekalipun keberhasilan itu kecil (Satisfaction).

Keberhasilan siswa memahami isi bacaan melalui penggunaaan teknik 
complete sentence ini mendukung teori belajar Gestalt. Teori Gestalt menyatakan bahwa kecenderungan seseorang adalah melengkapi bagianbagian yang belum lengkap dari sebuah totalitas secara keseluruhan (Suherli, dkk., 2006 : 11). Ini berarti, siswa akan merasa terbantu melengkapi kata terhadap kalimat-kalimat teks bacaan yang belum lengkap yang pada akhirnya membantu dalam proses pemahaman isi bacaan.

\section{Simpulan}

Berdasarkan pemaparan laporan hasil penelitian ini, berikut disampaikan beberapa simpulan dan saran.

(1) Penerapan Model Pembelajaran ARIAS dengan berbantuan Teknik Complete Sentence dapat meningkatkan respon dan aktivitas siswa dalam pembelajaran membaca. Hasil siklus I dan II menunjukkan respon siswa positif dalam pembelajaran.

(2) Penerapan Model Pembelajaran ARIAS dengan berbantuan Teknik Complete Sentence dalam pembelajaran membaca dapat meningkatkan kompetensi siswa dalam memahami isi bacaan. Sebelum tindakan atau pada tes awal nilai ratarata siswa 59,52 dengan ketuntasan
$21,43 \%$ meningkat menjadi 69,05 dengan ketuntasan $61,90 \%$ pada siklus I dan 72,50 dengan ketuntasan 80,95\% pada siklus II.

(3) Atas simpulan (1) dan (2) di atas, maka pembelajaran membaca dengan penerapan Model Pembelajaran ARIAS dengan berbantuan Teknik Complete Sentence dapat meningkatkan mutu pembelajaran membaca.

\section{Saran-Saran}

Berdasarkan simpulan di atas maka penulis mengajukan beberapa saran berikut.

(1) Guru-guru mata pelajaran Bahasa Indonesia pada Satuan Pendidikan SMP/MTs disarankan untuk menerapkan hasil penelitian ini dalam pembelajaran membaca dengan kemungkinan dikondisikan dengan karakteristik kelas yang dihadapi.

(2) Dalam penelitian ini, dalam proses pembelajaran baru terbatas pemberian satu model teks bacaan yang kalimat-kalimatnya belum lengkap dalam tiap siklus, maka untuk diperoleh hasil yang lebih valid perlu dilakukan penelitian lanjutan dengan memperbanyak memberikan model 
teks bacaan yang kalimat-kalimatnya belum lengkap dengan beragam topik.

\section{DAFTAR PUSTAKA}

Anonim. Hakikat Membaca - Proses Membaca. Tersedia di http://tarjo 2009.blogspot.com/2009/03.

Anonim. Model-Model Pembelajaran. Tersedia di http://wijayalabs. Wordpress.com/2008/04/22.

Departemen Pendidikan Nasional. 2004. Standar Kompetensi Mata Pelajaran Bahasa Indonesia. Jakarta: Departemen Pendidikan Nasional

Departemen Pendidikan Nasional. 2005. Materi Pelatihan Terintegrasi Kurikulum 2004 Bahasa dan Sastra Indonesia. Jakarta: Departemen Pendidikan Nasional

Gredler, M.E.Bell. 1991. Belajar dan Membelajarkan (penerjemah Munandir). Jakarta: Rajawali.

Nuriadi. 2008. Teknik Jitu Menjadi Pembaca Terampil. Yogyakarta: Pustaka Pelajar

Rahim, Farida. 2007. Pengajaran Membaca di Sekolah Dasar. Jakarta: Bumi Aksara

Santyasa, I Wayan. 2006. Penelitian Tindakan Kelas: Konsep Dasar, Teknik PenyusunanProposal, dan Sistematika Laporan Penelitian (Makalah). Singaraja: Universitas Pendidikan Ganesha.

Soedarsono. 2002. Speed Reeding

Sistem Membaca Cepat dan Efektif. Jakarta: Gramedia Pustaka Utama

Suherli, H. dkk. 2006. Keterbacaan Buku Teks Pelajaran Sekolah Dasar (Laporan Penelitian). Jakarta: Pusat Perbukuan.
Tarigan, Henry Guntur. 1998. Membaca sebagai Suatu Keterampilan Berbahasa. Bandung: Angkasa 